\title{
Synthesis of New Azole Phosphonate Precursors for Fuel Cells Proton Exchange Membranes
}

\author{
Fátima C. Teixeira, ${ }^{1}$ C. M. Rangel,${ }^{1}$ and António P. S. Teixeira ${ }^{2,3}$ \\ ${ }^{1}$ Laboratório Nacional de Energia e Geologia, I.P., Estrada do Paço do Lumiar, 22, 1649-038, \\ Lisboa, Portugal \\ ${ }^{2}$ Departamento de Química, Escola de Ciências e Tecnologia, Centro de Química de Évora, \\ Instituto de Investigação e Formação Avançada, Universidade de Évora, R. Romão Ramalho, 59, \\ 7000-671, Évora, Portugal \\ ${ }^{3}$ Centro de Química Estrutural, IST, Universidade de Lisboa, Av. Rovisco Pais, 1, 1049-001, \\ Lisboa, Portugal
}

Received 23 July 2014; revised 17 October 2014

\begin{abstract}
Herein we present the synthesis and characterization of new phosphonate-, bisphosphonate- and hydroxybisphosphonatebenzimidazole derivatives substituted at the N-1 position and new regioisomers phosphonate-, bisphosphonate-, and hydroxybisphosphonatebenzotriazole derivatives substituted at $\mathrm{N}-1$ or $\mathrm{N}-2$ positions. The compounds were characterized by NMR and IR spectroscopies, and mass spectrometry (low and high resolution) allowing the assignment of their structure, including the identification of regioisomers. These new azole monomers will be precursors for a mesoporous silica host to produce novel membrane materials with high proton conductivity for intermediate temperature proton exchange membrane fuel cells. (c) 2015 Wiley Periodicals, Inc. Heteroatom Chem. 26:236-248, 2015; View this article online at wileyonlinelibrary.com. DOI 10.1002/hc.21254
\end{abstract}

Correspondence to: Fátima C. Teixeira; e-mail: fatima. teixeira@lneg.pt.

Supporting Information is available in the online issue at www.wileyonlinelibrary.com.

(C) 2015 Wiley Periodicals, Inc.

\section{INTRODUCTION}

In an energy scenario that increasingly demands cleaner and more efficient energy sources, fuel cells are considered promising electrochemical devices since they can provide electric energy with high efficiency and low environmental impact, converting the energy stored in fuels with zero pollution levels. The proton exchange membrane fuel cells (PEMFC) are considered one of the most promising sources among the various kinds of existing fuel cells due to their high power density and high power-to-weight ratio. One of the drawbacks of current cells is related to the electrolytes currently in use, limiting their use to temperatures below $100^{\circ} \mathrm{C}$ when operating under water-assisted proton conduction.

The temperature operation above $100^{\circ} \mathrm{C}$ could increase the performance of PEMFC due to a faster electrode reaction without $\mathrm{CO}$ poisoning of the $\mathrm{Pt}$ electrocatalyst, easier heating, and high energy efficiency [1-8].

The proton exchange membrane is a key component for the operation of PEMFC. During recent years, the study of membrane materials have been focused in obtaining high proton conductivity, low electrical conductivity, low permeability to fuel and oxidant, good chemical and thermal stabilities, good mechanical properties, and low cost [1-8]. 